\title{
Wisdom and lifelong learning in the twenty-first century
}

\author{
Richard Hawley Trowbridge* \\ Bryant and Stratton College, New York, USA
}

While research indicates that humans tend potentially to develop towards wisdom in later years, a review of mainly participant-determined groups and courses in 338 lifelong learning centers for older people shows little interest in wisdom or personal development activities. With the suggestion that this apparent lack of interest may be partially owing to the lack of programs for cultivating wisdom, a model is presented that can be practised both independently and in formal education settings, and whose results can be assessed.

\section{Introduction}

It may be that today we are in the same relation to wisdom as Homo erectus was to language: we have barely started down the path. Much of our knowledge about Earth, the universe, life and human development is very new. In a universe where time is measured in intervals of a million years, it might be wise to consider that the great teachers throughout history did not provide final truths, but way stations at the beginning of a long journey. The level of human wisdom is indicated by the wars Homo sapiens is presently undertaking, and the money being spent on weapons compared with that spent on cultivating mental and physical wellness. A further gauge is the extent to which the average human attains full cognitive, emotional, social, and spiritual potential. We seem closer to a barbarian than to a sage society.

As a value or as a topic of academic interest, wisdom had been all but forgotten in the West until around the time of Gabriel Marcel's The decline of wisdom (1955). New perspectives on wisdom from philosophy (e.g., virtue ethics) then began to come forth; and new perspectives from theology, with rediscovered interest in the sapiential tradition. In psychology, the empirical study of wisdom began in the 1970s. On wisdom's return, we discern in it features that don't seem to have been present in earlier eras.

\footnotetext{
* Department of General Education, Bryant \& Stratton College, 1225 Jefferson Rd., Rochester, NY I4623,
} USA. Email: transletix@hotmail.com 
Although it has been hardly heard from for over 200 years, it is clear that wisdom has not become a period-piece but has kept pace with the advance of scientific knowledge. Wisdom is discussed in terms of such up-to-the-minute concepts as postformal thought, metacognition, and emotional and social intelligence. Wisdom assumed without delay its place as the integrating and all-encompassing concept for higher order mental, social and spiritual virtues (Baltes \& Staudinger, 2000; Baltes, 2004)—an updated statement of the ancient formula, sapientiae est ordinare. Certainly an attractive topic given the global problematique.

Much of the recent academic discussion of wisdom concerns its nature and definition. (In a later section of this article- 'Wisdom and Skill'-a definition is provided.) This is a necessary and instructive exercise, but whatever 'wisdom' means, and conceding that we will never be wise, there is evidence that many individuals, and humanity in general, can make transformational progress in becoming wiser, in a short time. If this is to occur, one key may be to bring quality programs for developing wisdom to lifelong learning centers for older adults. This article presents: (I) an overview of demographics of the ageing population; (2) developmental possibilities for matured people, and their relation to wisdom; (3) a survey of courses related to wisdom in lifelong learning programs for older people; (4) a description of the Wisdom as Skill program; (5) concluding thoughts.

\section{Demographics of an ageing population}

For most of the twentieth century, there was little interest in older people by psychologists, and less recognition that ageing provides possibilities beyond decline. James E. Birren, one of the first to take a more positive approach, points out (1999, p. 460) that scientific study of ageing began in the late twentieth century. Due in large part to demographics and finances, this period of neglect is rapidly ending. There are 76 million residents of the US who are 'baby-boomers', born between 1946-1964, slightly over $25 \%$ of the US population. The generation senior to them consists of 59 million living people in the US; together these generations are changing the center of demographic gravity in this country. In the UK (England and Wales), almost $40 \%$ of the population was 45 -years-old or older in 200 I (Office of National Statistics, 200I, Table KSO2). 'As we begin the twenty-first century', Kinsella and Velcoff (200I, Pp. I, 3) point out, 'population aging is poised to emerge as a preeminent worldwide phenomenon. ... The coming growth, especially of the oldest old [i.e., over 80-years-old], will be stunning'.

Until living memory, the average length of life did not extend far beyond childbearing and -raising years. In the UK and in the US, average expected lifespan at birth has risen 30 years since 1900. In a recent New York Times article describing the dramatic improvements in health among older people (Kolata, 2006), the University of Chicago's Robert W. Fogel is quoted as observing that advances in longevity and health in the past hundred years are 'unique among the 7000 or so generations of humans who have ever inhabited the earth'. While this cohort is larger in the US than elsewhere, the number of old people alive today worldwide is greater than ever, and they are better educated, healthier, more active, and better-off financially than the old have ever been (David, 200 I, p. 130). Characteristics of this unique cohort seem to provide an opportunity for 
creating a wiser global community, and for working out effective methods for facilitating attainment of optimal human development.

The material abundance lavished upon a large number of people in the second half of the twentieth century allowed a more expansive view of human nature and human potentials to come forth. Regarding physical and mental health, after the Second World War attention has focused increasingly on prevention relative to cure, and in healthy development relative to pathology (World Health Organization, 1948). True, Ryff and Singer could observe in 1998 (p. I) that 'there has been no discernible progress in carrying these views to the scientific or practice realms'. But by now it has become possible to describe what amounts to a new dimension of human development, a new awareness utilizing many higher-order mental activities: metacognition, emotional and social intelligence, self-knowledge in depth, autonomy and interrelatedness, critical thinking. All these higher-order skills are integrated in wisdom. The psychological research of the past 30 years has permitted a science-based description of wisdom to be articulated, and steps to learning it have been hewn out. Great numbers of people in the 'developed' world are entering old age still healthy, technologically savvy and educated. They face the challenge of major life changes, as their children leave home and they leave their jobs. These challenges call for wisdom, a quality long associated with people who have lived long and seen much. Only recently have psychologists begun to recognize positive developmental possibilities for older people, often using the term wisdom to denote fulfillment of these potentials.

\section{Developmental tasks and possibilities for older people}

In 199I, Baltes et al. (pp. 127-128) wrote 'It is possible ... that the present-day cultural construction of human aging is akin to that of an underdeveloped, relatively 'illiterate' society' and that contemporary developmental scientists may have only a slight idea of what the possibilities for development in old age might be. This suggestion was echoed by feminist author Betty Friedan (1993, p. 87):

We have barely even considered the possibilities in age for new kinds of loving intimacy, purposeful work and activity, learning and knowing, community and care. ... For to see age as continued human development involves a revolutionary paradigm shift.

The years since these evaluations were made have been a time of extraordinary advances. Understanding of the ageing mind-brain has been revolutionized during and after the Decade of the Brain, an initiative of the US Library of Congress and the National Institute of Mental Health, which lasted throughout the 1990s. Much research on continuing development throughout the lifespan has been conducted, and many approaches tried.

Possibly the most influential model of human development in the twentieth century was Jean Piaget's (1932, 1966), which is restricted to intellectual and moral development and stops with the development of ability to carry out 'formal operations' in adolescence. Sigmund Freud's (1935) model of psychosexual development likewise ends in adolescence with the 'genital stage' of maturing sexual interest.

Erik Erikson (1950), whose work was based on the psychoanalytic theory of Freud, provided the first (and still dominant) model of psychosocial development to extend 
throughout the lifespan. The last two of his eight stages ('tasks' has been suggested as a preferable term) involve the development of care-'a widening commitment to take care of the persons, the products, and the ideas one has learned to care for' (1997, p. 67) —and wisdom through successfully resolving the choices of generativity versus stagnation, and integrity versus despair. In fact, empirical study of wisdom began with the questioning of this model (Clayton, 1975, 1976. Erikson did not mention wisdom until the second edition, 1963).

In his presentation of the results of the lengthiest observations of lifelong development, the Study of Adult Development at Harvard University, George Vaillant (2002, P. 40) follows a revised Eriksonian model for Aging well (the title of the book), adding a Freudian element of mature defense mechanisms. His research led him to concur with Erikson's identification of a widening circle of concern with increasing age (p. 44). This is observed particularly in the achievement of generativity: caring for the future of the larger community as well as passing along individually acquired learning. Vaillant describes the four 'critical components' of the latter years of life as maintaining a sense of well-being despite illness; creativity and playfulness; acquiring wisdom; and cultivating spirituality (p. 37).

Since the 1970s, Piaget's model has been augmented by psychologists who consider additional life domains than he did, and recognize the occurrence of mental development beyond the mastery of formal operations. Later development has the goal of meshing the individual with his or her larger context, and achieving a sense of meaning, according to Jan Sinnott. Mastering postformal operations allows 'for conscious orchestration of emotional and cognitive life, leading to emotional self-regulation ... maturity, and wisdom' (1998, p. 55). Neopiagetian Juan Pascual-Leone believes that wisdom is 'the ultimate possible achievement of a normal person's growth'. It is the integration of the totality of a person's being, when it 'reaches sufficient breadth and cohesiveness', that allows wisdom to appear (1990, p. 245).

Two earlier psychological models of late life development can be mentioned. Carl Jung distinguished two stages in the lifecourse: during the first half, the individual's task is to establish him- or herself in the outer world, attaining a developed ego. In the second half of life, one goes within, seeking integration and harmony, ideally 'building up a state of wider and higher consciousness' (Jung, 1969, p. 393) beyond the perspective of the individual organism. More recently, Jung's observation that with ageing there is a shift from extraversion to introversion has been confirmed by Chris Beckett (2002, p. 200). Beckett observes that this growing inwardness corresponds to Erikson's view of the tasks of later life. Much in agreement with Jung's position, Harry R. Moody claims that 'In psychodynamic terms, the process of life review constitutes the major developmental task of old age, and it is the fundamental question for any philosophy of aging' (1978, p. 34). In his experience, Moody, whose career has been spent in studying the psychology of old people, has 'always found' a desire of old people to tell their story, to make sense of their experience.

Abraham Maslow's concept of self-actualization, while considered to be a lifelong process, was reserved for older people. 'In our culture at least, youngsters have not yet achieved identity, or autonomy ... nor have they generally become knowledgeable and educated enough to open the possibility of becoming wise' (1970, p. xx). Maslow believed 
that only I\% of the population was self-actualizing (I968, p. 204). Many are unable to selfactualize due to economic and social barriers raised against people of their gender, religion and race. It should be clear that in contemporary society few will achieve the development of wisdom. It is worth entertaining Maslow's estimate that, as Ruth Cox mentions in her 'Afterword' to the third edition of Motivation and personality (1987, p. 263) 'a society with 8 percent self-actualizing people would soon be a self-actualizing society'.

Current models of healthy ageing present two distinct views on optimal development in the latter years of the lifespan, which can be designated as successful ageing and conscious ageing. Both contribute to optimal ageing: the former to optimization of one's physical and mental abilities in the face of age-related decline, and the latter to finding meaning in one's life and place in the universe, and accepting decline and mortality. Successful ageing, as described by Rowe and Kahn (1998) in presenting the results of the MacArthur Foundation Study of Aging in America, is characterized by low risk of disease, high mental and physical functioning, and active engagement with life. Success means continuing to function at optimal physical and mental level; wisdom is not necessarily involved. Conscious ageing, on the other hand, requires a long, arduous effort to go beyond the ego structures one has built throughout a lifetime to find a home for one's identity in a larger, transpersonal entity. H. R. Moody (2003, p. I43) states that 'World wisdom traditions regard this course of transcendence as a human being's struggle to overcome the self. While conscious ageing includes the Eriksonian challenge of achieving integrity versus declining into despair, its ego transcendence aspect is not part of Erikson's model. Moody predicts that successful ageing will appeal to more people, as it aligns well with cultural values of success, productivity and youth. It does not require a reevaluation of one's identity or values.

The accuracy of Moody's view appears from an analysis of major policy reports in the UK on lifelong education, which 'reveals a strong priority accorded to vocational education and training in spite of some general rhetoric about the non-economic, personal and social benefits of lifelong learning' (Withnall, 2000). Richard Taylor (2005, p. 104) concludes that 'the whole thrust of the Labour Government's policy [regarding lifelong learning] has been market oriented'. In the US, a recent report in the New York Times (Olson, 2006) discusses the role of community colleges in providing ongoing education for baby boomers in their retirement. The colleges appear entirely focused on helping provide 'the credentials and training they will need to reposition themselves for second careers'. This is prototypical successful ageing. An elegant heuristic for successful ageing that applies to at least some aspects of wisdom is provided by leading geropsychologist Paul B. Baltes' model of 'selection, optimization, and compensation' (Baltes \& Freund, 2003; Baltes et al., 2005).

A model of conscious ageing is Lars Tornstam's (1997) gerotranscendence, which he regards as 'the final stage in a natural progression towards maturation and wisdom'. Tornstam describes gerotranscendence as a shift to a transpersonal perspective, with intrapersonal, interpersonal, and cosmic aspects.

The distinction made between instrumental and expressive activities (Havighurst, 1976; Londoner, 1978), often used for describing the motivations of older learners, is similar to that between successful and conscious ageing. Instrumental activities are those engaged in for the sake of achieving an external goal, usually in the future. Expressive activities are 
pursued for their intrinsic satisfaction. Manheimer's distinction between adaptational and transformational theories of development (Manheimer et al., 1995) is also comparable to the successful-conscious division.

The possibilities for continuing mental development in later years rest on a distinction between fluid and crystallized intelligence. The former refers to the speed and accuracy of mental processes, the latter to acquired knowledge and its successful application. While in activities depending on fluid intelligence performance has been found to decline with age, in those utilizing crystallized intelligence, ageing can correlate with improved performance. Although in their research Paul B. Baltes and his colleagues have found that increasing age generally does not correlate with increasing wisdom-related performance, or WRP (Staudinger, 1999, P. 660), older people are disproportionately represented among the highest scorers on their tests for measuring WRP. A useful finding of their research is that increasing age has both wisdom-increasing and wisdom-diminishing potentials. Greater experience and personal growth facilitate increases in wisdom, while declines in cognitive abilities, decrease in openness to new experience, and greater mental rigidity act against the increase of wisdom (Staudinger, 1999). It is research into crystallized intelligence, or 'cognitive pragmatics', that led to the pioneering empirical study of wisdom by Baltes and his colleagues at the Max Planck Institute for Human Development and Education (Baltes, 1993, p. 585).

The possibilities for psychosocial development in old age according to these sources can be summarized as:

- Enduring illness and loss without undue diminishment of activity and good spirits;

- A widening circle of caring for and taking care of.

- Post-formal thought-recognition of the validity of differing reality systems, and monitoring and regulating thoughts and emotions.

- Self-actualization (including creativity, a sense of play, learning how to live well).

- Deepening self-knowledge, integrating all aspects of one's person, setting the personal self in a larger context and identifying with that context.

- Gaining of wisdom, the culmination of human development.

To what extent does this occur? Particularly the last three achievements, which require a good deal of introspection and reflection? It is a worthwhile question to ask, as the advent of great numbers of older people, for the first time in history, offers the opportunity to discover and encourage their full psychosocial maturation. Such development will in turn promote more sustainable economic practices, and long-term and holistic perspectives, benefiting the entire human community. Post-baby boom generations may have to cope with a lowered standard of living, environmental crises and violent global conflicts. Marcel (1955), noting the neglect of wisdom in the modern world, suggested that the concurrent devaluing of older people is undoubtedly connected with the devaluation suffered by wisdom itself' (p. 40). This might be the opportune moment to change the low regard in which elders have been held in industrial societies, and assist people in older years find a role as stewards and transmitters of more thoughtful and encompassing cultural values. There is ample reason to link wisdom promotion with ongoing psychosocial development of older people. 


\section{Lifelong learning for the elderly}

Jung, Erikson and Tornstam may be correct in maintaining that there is a natural tendency to turn inward and grow wiser as one approaches death; but it is not likely that this can be accomplished optimally without guidance. There is little social support for accomplishing tasks such as deepening self-knowledge, achieving ego-integration and -transcendence, and gaining wisdom; and expecting older people to do so on their own is unrealistic. One venue for instruction in the requisite skills is learning in retirement centers. These are a relatively recent phenomenon, whose history beyond the forerunner stage dates to the 1970s. In this section I examine the existence of wisdom-oriented groups in two such institutions: the University of the Third Age (U3A) in the UK, and in Institutes for Lifelong Learning (ILLs) in the US.

The University of the Third Age began in France in the early 1970s, utilizing university sites and resources to offer summer courses for retired people. This proved popular, and in 198I the first U3A in Britain was established at Cambridge. It was decided that restriction to university sites was too limiting, and subsequently U3As were set up wherever enough people were interested. Today there are 614 U3As in the UK, and over 167,000 members (U3A \& Third Age Trust, 2007). They offer ongoing groups, as well as one-time events, in which volunteer members share their knowledge and experience. All people of appropriate age are welcome to participate, and often the quality of the groups is highfor example, organized by people who were professionally involved in the areas covered. For this study I searched the web pages of 145 such U3As, to identify all the ongoing groups (about 4300) and those focused on wisdom, and more broadly, on areas of selfdevelopment such as psychology and philosophy.

Institutes for Lifelong Learning began in 1962 with the Institute for Retired Professionals at Manhattan's New School for Social Research. By the late 1970s there were half a dozen such organizations. In the late 1980s, Elderhostel (which itself began in 1975) formed a network for such organizations, almost all of which are sponsored by universities and colleges, and usually offer participants access to the school's resources. Today there are over 300 member organizations of the Elderhostel Institute Network (EIN) and an estimated 500 such ILLs throughout North America (Elderhostel, 2007). I searched the web pages of all EIN affiliated organizations with a website, identifying those courses focused on wisdom or self-development among the roughly 6000 courses at 193 such Institutes.

The review of I45 U3A centers found 54 centers with at least one group (a total of 72 groups) with either a definite or possible relation to wisdom, or personal development towards wisdom. Groups are formed according to members' interest, so the presence or absence of wisdom-oriented groups is at least an indication of what the members, who may be considered above average in their interest in learning, find important. There are 21 groups which appear to be definitely oriented toward wisdom or wisdom-related concerns; for 39 of the 72 no details are provided (including 26 philosophy groups). In identifying wisdom-oriented groups, I tried to err on the side of inclusion. Most of the 4300 groups are engaged in language study, music appreciation or performance, health concerns and physical activities, arts and crafts, and history and current events. No doubt 
I have failed to include some groups that are connected with wisdom or personal development, but the conclusion is inescapable that, at least in their U3A participation, U3A members are far more interested in externally focused, objective activities than in development of abilities concerned with wisdom, self-transformation, or explicit personal development.

The same holds for ILLs in the US. Of the roughly 6000 classes or activities in 193 different ILLs, I found I8I wisdom- or personal development-related classes offered in 81 different institutions.

These findings raise a question concerning the claim that people tend to turn inward as they age. It may be naïve to expect that people in our societies, who get little experience with introspection for the first $\mathbf{5 0}$ years of their lives, would be able to respond adeptly to any urges in later life toward introspection, life review, or the development of wisdom. Coleman (2005, p. 304), points out that life review, requiring skilled introspection, may not be an activity most people engage in. It is certainly unrealistic to expect them to be able to do so as productively as they would if trained in reflective thinking.

If there is this small number of groups or courses for wisdom or explicit self-development in these centers, where participants set the curriculum, the conclusion has to be either that older people don't want self-development, or they don't want selfdevelopment in this context. Perhaps they are getting it indirectly through the other courses or groups-the humanities courses, discussion groups, walking groups, social activities - or in other venues. The 'self-help' section of bookstores is certainly filled with bestsellers that are wisdom-related at least in the broad sense followed in this study. In its study of the baby boomers, the American Association of Retired People (AARP, 2005) reported that less than a third of the respondents were very satisfied with their leisure activities. Leisure activities and religious or spiritual life were the areas in which improvement is most desired (pp. 43-46). This would seem to indicate potential interest in wisdom development.

Yet the older people actively pursuing lifelong learning in ILLs or the U3A do not appear very concerned with wisdom: it seems that the proportion of wisdom-oriented classes would be just as large in groups of people in their 40s, 30s, or 20s. Not what one would expect from reading Erikson or Jung.

Kim and Merriam (2004) note that there have been few studies on motives of older people for participating in learning activities. In their citations, the most recently published, before their own survey administered to 189 participants in a learning in retirement (LIR) institute, is 1993. Kim and Merriam found cognitive interest to be a significantly greater motivation than the other three factors contained in their study (social contact, family togetherness, social stimulation). In discussing the research on motivations for participation in institutes for LIR, Martin (2003, p. 3) observes that 'cognitive interests always prove to be the strongest motivator, followed by a desire for socialization'.

An examination of courses and groups in LIRs, and of studies on motivations of older people for participating in formal learning activities, do not take us very far in identifying their developmental needs. In any case, as these needs may be dimly sensed and receive little encouragement in society, the only way to identify them might be to begin with a theory and then to test it in the real world. 
Alternatively, the needs can be identified by monitoring the interests actually demonstrated by older people, particularly their self-chosen informal learning, outside of enrollment in college courses or participation in LIRs. Yet this still leaves out that which people desire but are unable to articulate. In focus group interviews with 45 long-term members of an LLI, Lamb and Brady (2005) found 'opportunities for spiritual renewal' to be one of four major categories of perceived benefits-a result unanticipated by them. A straw in the wind, this finding supports the ideas of Jung and Erikson in regard to the developmental tasks of older people.

It should also be noted that most of the self-development/wisdom courses offered in ILLs are of limited duration, often no more than one to three sessions-a limitation that may account to some extent for the lack of wisdom focused courses. It's hard to go far in such a short time. (Many self-development/wisdom courses continue for eight weeks or so.) But dissatisfaction with course length would not seem to be a major factor. Language courses lasting eight weeks or less are popular; analogously, partial coverage of wisdom should be of interest - if people were interested in wisdom at all. And the U3A groups are ongoing. Perhaps the people who are working consciously toward wisdom are not those who participate in lifelong learning groups?

Or perhaps what is missing are models for a course in wisdom development. Manheimer et al. (1995, Pp. 21-22) note the skepticism originally expressed toward offering a federally funded humanities reading and discussion group series at senior centers (as being too advanced for the population), and their subsequent widespread popularity. Wisdom may be a goal toward which older people tend; but having become rather remote from common discourse, wisdom may need an accessible program to get the ball rolling. In facilitating courses on wisdom at learning in retirement centers, I have found considerable interest in the subject, and that participants are genuinely interested in the application of wisdom in their own lives. From reviewing the literature on older people's developmental needs and their motives for participation in learning activities, it appears likely that a course on wisdom will be most successful by also responding to elders' interest in cognitive enrichment and social participation. Such a program will be helpful both in elders' search for meaning and in providing a tool for optimal resolution of problems they encounter, meeting both instrumental and expressive goals.

Wisdom really needs better marketing. It would also help to have practical programs offering direct and immediate application of wisdom behaviours and attitudes in participants' own lives. It would help if participants could gauge the success and progress of their efforts. The rest of this article is devoted to a description of the program Wisdom as Skill: Developing and Living by a Wisdom Perspective (also referred to as The Wisdom-Centered Life). Perhaps this description will inspire others to develop similar, or better, programs. Wisdom as Skill is still very much in its initial stage: in summer 2007 it will be offered for the third time.

\section{Wisdom as Skill}

Wisdom as Skill is based on the empirical studies of wisdom and its ontogenesis (Trowbridge, 2005), the philosophic tradition of cultivating wisdom (see Hadot, 2002), 
and models of skill development (Dreyfus \& Dreyfus, 1986, 2004). The first attempt to put it into practice was made in autumn 2006 at a learning in retirement institution in western New York State.

In Wisdom as Skill, wisdom is defined as profound understanding of the basic realities of existence, living in alignment with them, and making the best possible choices conformant with this understanding. Basic realities of existence refer to, for example, suffering and death, good and evil; aesthetic appreciation of the world; the limits of human knowledge and emotional sensitivity; the natural tendency to perceive the world from a self-centered perspective; transcendence of the individual; recognition of basic equalities among all beings; possibilities of love and of awareness, happiness and misery. The definition is intended to be generic and traditional; participants are encouraged to adapt the definition, as long as it is clear what they mean by wisdom. A large collection of definitions and descriptions of wisdom that have been set forth throughout history is made available in the manual accompanying the course. About two dozen men and women participated in each of the first two courses, and there was ongoing discussion of the nature of wisdom as it appeared in participants' own lives.

The program consists of three main activities: (I) learning about wisdom; (2) developing and living by a wisdom perspective; and (3) practice with situations in the participant's own life in which she or he wants to exercise wisdom. 'Situations' is used in a broad sense, to include general reflections on one's progress toward wisdom and developing richer understanding of the meaning of existence.

Learning involves immersion in the religious, philosophical, and psychological literature on wisdom, and acquainting oneself with people or groups of people who manifest or manifested wisdom. The goal is to understand wisdom as described or exhibited by people who have dedicated much time to it. The assumption is that wisdom tends to be vaguely understood, and that a person's ability to embody and exhibit wisdom is limited by his or her clarity regarding what it is. To avoid confusion, it appears important to stress the evolving meanings of wisdom-wisdom as portrayed in the Old Testament, for example, is different from that of ancient or modern philosophers, contemporary psychologists, and even modern theologians.

Developing and living a wisdom perspective is accomplished by internalizing a number of principles, by learning and practising the character traits associated with wisdom (e.g., openness, reflectiveness, empathy, fairness and sound judgment, serenity, humor, selfknowledge, humility, a transpersonal perspective), and engaging in daily exercises. Following a hint by Hadot (2002, p. 244), a number of principles were collected; these are to be used for reflection, and to be internalized by participants.

For practising wisdom in life situations, the participant selects situations in his or her own life in which she or he would like to manifest greater wisdom. Attempts to do so are recorded in a journal, excerpts of which can be shared in small group activities (reflective case study), with a coach, or used for individual practice. As in models of expertise development, it is considered that optimal progress will be made by working on those areas that are just beyond the participant's current level of competence.

A rubric is provided by which efforts can be assessed by peers, by the individual, or by trained evaluators. Assessment is made according to six criteria (openness, centeredness 
and self-knowledge, reflection and holism, humility, empathy, rationality) that elaborate a single encompassing standard - the extent to which the response exemplifies and aligns with profound understanding of reality and represents the best possible choice in the situation in the light of this reality. There is a significant amount of overlap among the criteria. After assessing the belief or choice according to the criteria, its alignment with the encompassing standard is evaluated. The goal is that assessment should be as simple as possible while adequately assessing wisdom as defined.

As 'profound understanding of reality' is a matter of interpretation, and there is room for people who may be considered wise to hold quite different views regarding the nature of reality, the solution seems to lie in setting forth (I) the context of assumptions; (2) the manner in which one explores the nature of reality; and (3) the claims one makes regarding validity. Particular conclusions are subordinate-granted that it is the conclusions people have to live with.

It is likely that progress will be optimal when a person works with a partner, in a small group, or in a class conducted by a trained instructor; but working alone can be completely satisfactory.

\section{Conclusion}

For the first time in history, the balance of human interest is inclining toward the latter half of the uncurtailed lifespan. This half falls within the province of wisdom, at least potentially. Seventy-five million baby boomers in the US are entering the years during which a person naturally becomes very interested in the quality of life, in making sense of life, and in contributing positively to future generations.

Whether by chance or by necessity, it has only been in recent decades that wisdom has ceased to 'vanish almost entirely from the philosophical map' (Smith, Routledge encyclopedia of philosophy, 1998) and from the map of human interests altogether. Interest in wisdom on the part of the public is growing, accompanied by burgeoning interest from researchers. Philosophers' index lists II5 articles with wisdom as subject between 1940-1959; 220 between 1960-1979; 16I between 1980-1989; 238 between 1990-1999; 192 between 2000 and listings as of December 2006. Psychlnfo finds one article with wisdom as keyword between 1940-1959; seven between 1960-1979; 13 between 1980-1989; 57 between 1990-1999; 174 from 2000 to December 2006 (searches made December, 2006).

This interest is spurred not only by a huge approaching wave of vital old people, but also by social-economic conditions that demand more complex, higher-order mental functions, such as metacognition, emotional intelligence, reflective learning, critical thinking, and postformal thought. Higher-order mental functions, too, are within the domain of wisdom, which has been conceptualized as a metaheuristic for orchestrating mind and virtue toward excellence (Baltes \& Staudinger, 2000, p. 127). A wisdom perspective is the potential integrator of all input, evaluator of options, goals, and values, and planner and conductor of behaviour.

The revolutionary implications of a progression toward wisdom need to be emphasized. In the inaugural edition of the Journal of Transpersonal Psychology, Abraham Maslow wrote $(1969$, p. 6) that 'We are dealing with a new image of man'. This recalls the words of 
pioneer psychologist G. Stanley Hall, who, at the end of his life, expressed his conviction that 'nature is trying to bring into the world a new and higher and more complete humanity' (1922, p. 427). The current generation is the first to be able to bring the lifecourse to its natural fulfillment. For various reasons the time is propitious for a campaign to bring about a wisdom society.

The quickest and most effective path to creation of a wisdom society may be via the elderly. This is a group whose ability to complete a full lifecycle enables them to respond to the desire to leave a judiciously-chosen legacy, make sense of their lives, and develop the comprehensive understanding and character that is wisdom. Centers for learning in retirement may provide an ideal starting-point for this evolutionary step.

From what has been said about Homo sapiens' current attainment of wisdom, it is obvious that this paper is only an inchoative statement, leaving vital questions unraised. The biological basis of wisdom, gender differences, the ambiguities of human nature, productive approaches to conceptualizing the human condition, the organizing of priorities, the role of character and virtue in manifesting wisdom-and human limits in this regard-are some vexed questions awaiting future exploration. Also, understanding wisdom and optimal human development requires a multicultural approach going beyond the western focus presented here. Ways to include non-white, less formally educated and less financially secure people-who are poorly represented in learning in retirement institutions-need to be found. In the meantime, we can still go much farther than we have.

\section{Notes on contributor}

Richard Hawley Trowbridge teaches critical thinking and human relations courses for under-graduates, in addition to conducting courses in wisdom development for older people. He is currently completing a volume that integrates approaches to wisdom from philosophy, theology, and psychology, and proposes ways in which wisdom can be applied to contemporary problems of living.

\section{References}

American Association of Retired Persons (AARP) (2005) Boomers at midlife: the AARP life stage study wave 3, 2004. Available online at: http://assets.aarp.org/rgcenter/general/boomers_midlife_2004.pdf (accessed 26 January 2007).

Baltes, P. B. (1993) The aging mind: potential and limits, The Gerontologist, 33(5), 580-594.

Baltes, P. B. (2004) Wisdom as orchestration of mind and virtue. Book in preparation. Available online at: www.mpib-berlin.mpg.de/dok/full/baltes/orchestr/index.htm (accessed 26 January 2007).

Baltes, P. B. \& Freund, A. M. (2003) The intermarriage of wisdom and selective optimization with compensation: two meta-heuristics guiding the conduct of life, in: C. L. M. Keyes \& J. Haidt (Eds) Flourishing: positive psychology and the life well-lived (Washington, DC, American Psychology Association), 149-173.

Baltes, P. B., Freund, A. M. \& Li, S.-C. (2005) The psychological science of human aging, in: M. L. Johnson (Ed.) The Cambridge handbook of age and ageing (Cambridge, Cambridge University Press), 47-7I.

Baltes, P. B., Smith, J. \& Staudinger, U. M. (199I) Wisdom and successful aging, in: T. Sonderegger (Ed.) Nebraska symposium on motivation. Volume 39 (Lincoln, NB, University of Nebraska Press), 123-167. 
Baltes, P. B. \& Staudinger, U. M. (2000) Wisdom: a metaheuristic (pragmatic) to orchestrate mind and virtue toward excellence, American Psychologist, 55(I), 122-136.

Beckett, C. (2002) Human growth and development. (London, Sage).

Birren, J. E. (1999) Theories of aging: a personal perspective, in: V. L. Bengtson \& K. W. Schaie (Eds) Handbook of theories of aging (New York, Springer).

Clayton, V. (1975) Erikson's theory of human development as it applies to the aged: wisdom as contradictive cognition, Human Development, I8(1/2), II9-128.

Clayton, V. (1976) A multidimensional scaling analysis of the concept of wisdom. Unpublished dissertation, Los Angeles, CA, University of Southern California.

David, G. (200I) Aging, religion, and spirituality: advancing meaning in later life, in: F. L. Ahearn (Ed.) Issues in global aging (New York, Haworth Press), 129-140.

Dreyfus, H. L. \& Dreyfus, S. E. (1986) Mind over machine: the power of human intuition and expertise in the era of the computer (New York, Free Press).

Dreyfus, H. L. \& Dreyfus, S. E. (2004) From Socrates to expert systems: the limits and dangers of calculative rationality. Available online at: http://ist-socrates.berkeley.edu/ hdreyfus/html/paper_socrates. html (accessed 9 February 2006).

Elderhostel (2007) Elderhostel Institute Network. Available online at: http://www.elderhostel.org/ein/ intro.asp (accessed 14 January 2007).

Erikson, E. H. (1950) Childhood and society (New York, Norton).

Erikson, E. H. (1963) Childhood and society (New York, Norton).

Erikson, E. H. (1997) The life cycle completed (New York, W. W. Norton).

Freud, S. (1935) A general introduction to psycho-analysis (New York, Liveright).

Friedan, B. (1993) The fountain of age (New York, Simon \& Schuster).

Hadot, P. (2002) What is ancient philosophy? (Cambridge, MA, Belknap-Harvard University Press).

Hall, G. S. (1922) Senescence, the last half of life (New York, Appleton).

Havighurst, R. (1976) Education through the adult life span, Educational Gerontology, I(I), 4I-5I.

Jung, C. G. (1969) The stages of life, in: The collected works of C. G. Jung (Bollingen Series XX), Vol. 8: The structure and dynamics of the psyche (Princeton, NJ, Princeton University Press).

Kim, A. \& Merriam, S. B. (2004) Motivations for learning among older adults in a learning in retirement institute, Educational Gerontology, 30(6), 44I-455.

Kinsella, K. \& Velkoff, V. A. (200I) An aging world: 200I, US Census Bureau, Series P95/0I-I (Washington, DC, US Government Printing Office).

Kolata, G. (2006, July 30) So big and healthy grandpa wouldn't even know you, New York Times. Available online at: http://www.nytimes.com/2006/07/30/health/30age.html?ex=||829|6800\&en= 9aa044le9f0ad040\&ei=5070 (accessed 12 June 2007).

Lamb, R. \& Brady, E. M. (2005) Participation in lifelong learning institutes: what turns members on?, Educational Gerontology, 3I(3), 207-224.

Londoner, C. A. (1978) Instrumental and expressive education: a basis for needs assessment and planning, in: R. H. Sherron \& D. B. Lumsden (Eds) Introduction to educational gerontology (Washington, DC, Hemisphere).

Manheimer, R., Snodgrass, D. D. \& Moskow-McKenzie, D. (1995) Older adult education: a guide to research, programs, and policies (Westport, CT, London, Greenwood Press).

Marcel, G. (1955) The decline of wisdom (New York, Philosophical Library).

Martin, C. (2003) Learning in retirement institutes: the impact on the lives of older adults, Journal of Continuing Higher Education, $5 \mathrm{I}(\mathrm{I}), 2-1 \mathrm{I}$.

Maslow, A. H. (1968) Toward a psychology of being (New York, Van Nostrand).

Maslow, A. H. (1969) The farther reaches of human nature, Journal of Transpersonal Psychology, I(I), I-9.

Maslow, A. H (1970) Motivation and personality (New York, Harper \& Bros.).

Maslow, A.H. (1987) Motivation and personality (New York, Harper \& Row).

Moody, H. R. 1978. Education and the life cycle: a philosophy of aging, in: R. H. Sherron, \& D. B. Lumsden (Eds.) Introduction to educational gerontology (Washington, DC, Hemisphere), 3I-47. 


\section{R. Hawley Trowbridge}

Moody, H. R. (2003) Conscious aging: a strategy for positive change in later life, in: J. L. Ronch \& J. A. Goldfield (Eds) Mental wellness in aging: strengths-based approaches (Baltimore, MD, Health Professions Press), 139-160.

Office of National Statistics (200I) Table KS02 Age structure, census 200I: key statistics for the rural and urban area classification 2004. Available online at: www.statistics.gov.uk/StatBase/Expodata/Spreadsheets/D8915.xls (accessed 26 January 2007).

Olson, E. (2006, October 24) Community colleges want you, New York Times. Available online at: http://www. nytimes.com/2006/I0/24/business/retirement/24educ.html?ex $=|3|$ | $3342400 \& e n=d 54 \mid$ ee2a2c8202cd \&ei $=5088 \&$ partner $=$ rssnyt\&emc $=$ rss (accessed 12 June 2007).

Pascual-Leone, J. (1990) An essay on wisdom: toward organismic processes that make it possible, in: R. Sternberg (Ed.) Wisdom (Cambridge, Cambridge University Press), 244-278.

Piaget, J. (1932) The moral development of the child (New York, Harcourt, Brace \& World).

Piaget, J. (1966) The psychology of intelligence (Totowa, NJ, Littlefield, Adams \& Co).

Rowe, J. W. \& Kahn, R. L. (1998) Successful aging (New York, Pantheon).

Ryff, C. D. \& Singer, B. (1998) The contours of positive human health, Psychological Inquiry, 9(I), I-28.

Sinnott, J. D. (1998) Creativity and postformal thought: why the last stage is the creative stage, in: C. E. Adams-Price (Ed.) Creativity and successful aging: theoretical and empirical approaches (New York, Springer), 43-72.

Smith, N. D. (1998) Wisdom, in: E. Craig (General Ed.) Routledge encyclopedia of philosophy (London, Routledge), 752-755.

Staudinger, U. (1999) Older and wiser? Integrating results on the relationship between age and wisdomrelated performance, International Journal of Behavioral Development, 23(3), 64I-664.

Taylor, R. (2005) Lifelong learning and the Labour governments 1997-2004, Oxford Review of Education, $3 \mathrm{I}(\mathrm{I}), \mathrm{I0I}-\mathrm{II} 8$.

Tornstam, L. (1997) Gero-transcendence: the contemplative dimension of aging, Journal of Aging Studies, II (2), I43-I54.

Trowbridge, R. H. (2005) The scientific approach to wisdom. Unpublished doctoral dissertation. Available online at: www.cop.com/TheScientificApproachtoWisdom.doc (accessed 26 January 2007).

University of the Third Age/Third Age Trust (2007) Home page. Available online at: www.u3a-info.co.uk (accessed I 4 January 2007).

Vaillant, G. E. (2002) Aging well: surprising guideposts to a happier life from the landmark Harvard study of adult development (Boston, MA, Little, Brown \& Company).

Withnall, A. (2000) Older learners-issues and perspectives. Working papers of the Global Colloquium on Supporting Lifelong Learning. Available online at: www.open.ac.uk/lifelong-learning (accessed 12 December 2006).

World Health Organization (1948) Preamble to the constitution of the World Health Organization as adopted by the International Health Conference, New York, 19-22 June, 1946; signed on 22 July 1946 by the representatives of 6I States (Official Records of the World Health Organization, no. 2, p. I00) and entered into force on 7 April 1948. 